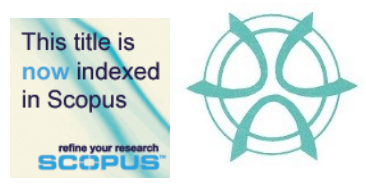

PLANNING MALAYSIA:

Journal of the Malaysian Institute of Planners

VOLUME 18 ISSUE 2 (2020), Page 37 - 46

\title{
ACTIVE FIRE SAFETY MEASURES IN THE HERITAGE TIMBER BUILDINGS IN MALAYSIA
}

\author{
Nurul Hamiruddin Salleh ${ }^{1}$ \& Muhammad Alif Wajdi Mohtar ${ }^{2}$ \\ ${ }^{1,2}$ Department of Architecture \\ Kulliyyah of Architecture \& Environmental Design \\ INTERNATIONAL ISLAMIC UNIVERSITY MALAYSIA
}

\begin{abstract}
Malaysia has a significant amount of heritage timber buildings located in every part of the country. The buildings symbolised the origin of the country's vernacular architectural style as well as the historical representation of the local community culture and its surrounding context. However, due to the combustible nature of timber, these heritage timber buildings are highly exposed to the risks of fire. Currently, there are no proper fire safety guidelines specifically for heritage buildings which can act as a good reference for the building owners or conservators in safeguarding the heritage buildings. The purpose of this study is to identify existing active fire safety measures in selected heritage timber buildings in Malaysia. The study was conducted through literature findings and observation of four selected heritage timber buildings. The study had identified that all four heritage timber buildings were equipped with very basic active fire safety measures.
\end{abstract}

Keywords: Fire Safety, Fire Risk, Heritage Buildings, Heritage Timber Buildings, Preservation

\footnotetext{
${ }^{1}$ Assistant Professor at International Islamic University Malaysia Email: hamiruddin@iium.edu.my
} 
Nurul Hamiruddin Salleh \& Muhammad Alif Wajdi Mohtar

Active Fire Safety Measures in the Heritage Timber Buildings in Malaysia

\section{INTRODUCTION}

For any civilisation or country, one of their most valuable historical assets is the existence of their heritage buildings. Heritage building can be easily depicted as a building constructed in the past which contains various historical value within its design or existence. The presence of heritage buildings contributes towards providing a general glimpse of the past of a specific community or civilization through the craftsmanship and technology used in the building's design and construction. In addition, the National Heritage Act 2005 further explained that the heritage building is defined as a building or groups of separated or connected buildings that stand out amongst the rest either due to their architectural essence, their cultural homogeneity, or even their placement within the surrounding landscape from the perspective of history, arts, and science.

Fire is a recurrent risk towards most buildings and its contents due to the various types of destruction and damages that it may cause. In the case of a heritage building, fire is considered a significant threat towards the historic essence of the building and its context especially with the increasing age for most of the building's material and lack of safety provision in most of the heritage buildings. Maxwell (2005) stated that fire usually occurs due to the presence of three main elements which includes heat, oxygen, and fuel. The spread of fire within the building also easily take place when it is unhindered from any types of separation. This is the main concern to heritage buildings since most of them were constructed using traditional methods and tend to include numerous voids that fire can easily spread through.

\section{RESEARCH BACKGROUND}

There had been reported that most of heritage buildings are exposed to fire risks (Nurul Hamiruddin \& A Ghafar, 2009; Othuman Mydin, Md Sani, Abas \& Khaw, 2014; Farid Wajdi, Wan Syarifah Nadirah \& Baaki, 2016). Among the common factors are (1) existing structures weak on fire resistance; ageing or decaying building materials and combustible materials; (2) inadequate fire prevention and protection systems, notably passive fire protection; (3) poor fire safety awareness among the building owners, managers, staff and the public; (4) low standard of management, housekeeping and maintenance; (5) locations of a few heritage buildings are at the busiest area or narrow road with no good access for fire brigade; (6) existing electrical wiring had not been upgraded or replaced accordingly; a few heritage buildings are still using old electrical wiring that may cause electrical fault; (7) storage for many flammable artefacts or heritage collections; (8) a large number of visitors; most heritage buildings open daily to the public; (9) the danger from renovation works; (10) possible danger from natural factors such as lightning, overheating etc.; and (11) the danger of carelessness or arson. 
Statistically, electrical faults are reported as the second highest cause of building fires in Malaysia (Table 1).

Table 1: Statistic on the cause of building fire in Malaysia from 2015 to 2018

\begin{tabular}{cccc}
\hline Year & $\begin{array}{c}\text { Fire Caused by } \\
\text { Electrical Faults }\end{array}$ & $\begin{array}{c}\text { Total Fire } \\
\text { Incident }\end{array}$ & $\begin{array}{c}\text { Percentage } \\
(\%)\end{array}$ \\
\hline 2015 & 1,233 & 22,456 & $5.6 \%$ \\
\hline 2016 & 2,005 & 44,672 & $4.5 \%$ \\
\hline 2017 & 1,737 & 27,681 & $6.3 \%$ \\
\hline 2018 & 1,563 & 34,769 & $4.5 \%$ \\
\hline & & Source: https://www.bomba.gov.my
\end{tabular}

Rozrinda and Shahrul Yani (2017) highlighted that a few studies had been conducted on fire safety for heritage buildings in Malaysia. The findings found that the level of the fire safety management system at heritage buildings in Malaysia is still low.

\section{METHODOLOGY}

This study employed a combination of both quantitative \& qualitative methods that divided into four (4) stages. The first stage involved a literature review, where both conservation and general fire safety literature were reviewed to identify key issues and recent research that relate or were significant to the research topic. The second stage involved the collection of primary data through interviews and observations. The interview sessions specifically involved the fire expects (e.g. the Fire and Rescue Department Malaysia (FRDM) officers and fire engineers). The interviews were conducted mainly to gather information on the current active fire protection systems and their application in heritage buildings. In the third stage, four (4) heritage timber buildings were selected as the case studies to observe directly the application of active fire protection measures in the buildings. The selected buildings are (1) Istana Ampang Tinggi, Seremban, Negeri Sembilan, (2) Negeri Sembilan Traditional House, Seremban, Negeri Sembilan, (3) Muzium Matang, Perak, and (4) Muzium Kota Kuala Kedah, Kedah. In the observation stage, the existing active fire protection measures in the buildings were briefly audited and manually recorded in a Fire Safety Checklist Form (a modified version of Form I (Reg. 2) of the Fire Services Act 1988) as well as taking photos for research purposes. In the last stage, conclusions were made based on the analysis of the literature and the collected data. 
Nurul Hamiruddin Salleh \& Muhammad Alif Wajdi Mohtar

Active Fire Safety Measures in the Heritage Timber Buildings in Malaysia

\section{HERITAGE TIMBER BUILDING}

Traditionally, timber was the main choice of material for the construction of traditional palaces, masjids and houses in Malaysia. Timber was considered as the easiest accessible material and the most economical building material at the time. There is a significant amount of heritage timber buildings in Malaysia and most of them are still in existence until today (Table 2). The buildings are categorised into five (5) main building typologies, namely place of worship, residential, office, palace and commercial building. Most of the buildings gazetted under the National Heritage Act 2005 as National Heritage Building or Heritage Building.

Table 2: List of several prominent heritage timber buildings in Malaysia

\begin{tabular}{|c|c|}
\hline $\begin{array}{c}\text { Building } \\
\text { Typologies }\end{array}$ & Name of Buildings \\
\hline $\begin{array}{l}\text { Place of } \\
\text { worship }\end{array}$ & $\begin{array}{l}\text { 1. Masjid Mulong, Kota Bharu, Kelantan } \\
\text { 2. Balai Adat Kampung Putera Jelebu, Negeri } \\
\text { Sembilan } \\
\text { 3. Masjid Kampung Laut, Kelantan } \\
\text { 4. Masjid Insaniah Iskandariah, Kuala Kangsar, } \\
\text { Perak }\end{array}$ \\
\hline Residential & $\begin{array}{l}\text { 1. Rumah Tiang Kembar \& Rumah Tiang Limas, } \\
\text { Terengganu } \\
\text { 2. Rumah Penghulu Mat Nattar, Jasin, Melaka* }\end{array}$ \\
\hline Office & $\begin{array}{l}\text { 1. Bangunan Sanitary Road, Taiping, Perak } \\
\text { 2. Muzium Islam, Kota Bharu Kelantan } \\
\text { 3. Kota Ngah Ibrahim, Taiping, Perak } \\
\end{array}$ \\
\hline Palace & $\begin{array}{l}\text { 1. Istana Lama Ampang Tinggi, Negeri Sembilan* } \\
\text { 2. Istana Jahar (Muzium Adat Istiadat Diraja), Kota } \\
\text { Bharu, Kelantan* } \\
\text { 3. Istana Kenangan (Muzium Diraja Perak), Kuala } \\
\text { Kangsar, Perak } \\
\text { 4. Istana Seri Menanti, Kuala Pilah, Negeri } \\
\text { Sembilan* }\end{array}$ \\
\hline
\end{tabular}

* Buildings gazetted under the National Heritage Act 2005

Source: https://www.heritage.gov.my

\section{HERITAGE TIMBER BUILDING RISKS TO FIRE}

A fire has a variety of reactions when exposed to a different type of materials. The type of materials used for the construction of a building can greatly influence the building's resistance to fire. This has always been a major concern since most of the heritage buildings in Malaysia were constructed using timber as the main 
material. Due to the combustible nature of timber materials, heritage timber buildings are greatly exposed to the risk of fire. According to Gerard \& Barber (2013), the presence of exposed timber material will contribute to the combustible fuel load as well as the room fire behaviour and structural fire resistance. Several heritage timber buildings in Malaysia have been damaged or destroyed by fire which results in a severe loss as shown in Table 3.

\begin{tabular}{ccc}
\multicolumn{1}{l}{ Table 3: Fire cases involved heritage timber buildings in Malaysia } \\
\hline Date & Building & $\begin{array}{c}\text { Estimated } \\
\text { Loss (MYR) }\end{array}$ \\
\hline 2 May 2003 & $\begin{array}{c}\text { 8 units of double-storey wooden } \\
\text { shop houses (1950), } \\
\text { Batu Kawa Bazaar, Kuching }\end{array}$ \\
\hline 25 July 2003 & $\begin{array}{c}\text { 138-year old semi-wooden girls' } \\
\text { dormitory, }\end{array}$ & 100,000 \\
& St Joseph Home, Penang \\
\hline 20 Oct. 2003 & $\begin{array}{c}\text { Rumah Pak Ali (1876), } \\
\text { Gombak, Kuala Lumpur }\end{array}$ & $>1$ mil. \\
\hline 5 May 2008 & $\begin{array}{c}\text { 38 units of Punan Bah longhouse, } \\
\text { Belaga, Sarawak }\end{array}$ & $>500,000$ \\
\hline 5 Feb 2009 & $\begin{array}{c}\text { 5 units of Heritage houses, } \\
\text { Chew Jetty, Penang } \\
\text { (In World Heritage Site Zone) }\end{array}$ \\
\hline 24 Feb 2010 & $\begin{array}{l}\text { Ho Ann Kiong Temple, } \\
\text { Kampung Cina, Kuala Terengganu }\end{array}$ \\
\hline
\end{tabular}

In comparison to other materials, the reaction of timber when exposed to fire consists of several different stages before the material is fully burned. According to the U.S. Department of Housing and Urban Development (2007), there are roughly four different stages of timber combustion. The first stage will occur at $100-150^{\circ} \mathrm{C}$, which the water inside the timber will start to evaporate and turn the timber brown. Upon reaching $200-250^{\circ} \mathrm{C}$, the charring process will slowly begin and non-combustible gas will be released. The third stage will occur at roughly $300^{\circ} \mathrm{C}$ where volatile and combustible gas is released, and smoke particles are becoming more visible. Finally, the fire will start to ignite at around $400-450^{\circ} \mathrm{C}$ and the charring process will occur at a steady rate. This will result in permanent loss of strength causing the breakdown of the timber.

Timber is considered to have an unpredictable combustion nature since the charring rate varies according to the type of timber exposed to fire. According to Lowden \& Hull (2013), the process is influenced by several different factors which include density, continuity, oxidation-resistance, thermal insulation properties and permeability. In order to overcome this situation, the Department 
Nurul Hamiruddin Salleh \& Muhammad Alif Wajdi Mohtar

Active Fire Safety Measures in the Heritage Timber Buildings in Malaysia

of Standards Malaysia (2001) had identified a notional charring rate of Malaysian timbers according to their strength group as a solution to ease the calculation of residual section as shown in Table 4. Through this reference, the process of estimating the amount of time needed to escape and fire prevention will be much easier.

Table 4: Notional rate of charring for the calculation of the residual section

\begin{tabular}{lc}
\hline \multicolumn{1}{c}{ Strength Group } & Charring Rate \\
\hline SG 1: Balau, Bitis, Chengal, Penaga & $0.5 \mathrm{~mm} / \mathrm{min}$ \\
SG 2: Belian, Kekatong & \\
SG 3: Keranji, Kelat, Kembang Semangkok, etc. & $0.7 \mathrm{~mm} / \mathrm{min}$ \\
\hline SG 4: Giam, Malabera, Merbau, etc. & \\
SG 5: Tembusu, Bintangor, Gerutu, etc. & Source: Department of Standards Malaysia 2001
\end{tabular}

\section{FIRE SAFETY APPROACH IN HERITAGE TIMBER BUILDING}

In order to prevent any potential risks of fire, great consideration should be made towards the implementation of an appropriate fire safety system for the heritage timber building. According to National Fire Protection Association (NFPA) (2015), one of the main objectives of historic preservation is to fully utilise the level of protection of the heritage building against damage and loss to fire. However, as highlighted by Kidd (2010) and Nurul Hamiruddin (2011), there are six different conservation principles to be considered during implementation of fire safety in a heritage building, which include (1) Essential, (2) Appropriate to risk, (3) Compliant with legislation, (4) Minimally invasive, (5) Sensitively integrated and (6) Reversible.

As stated by Urquhart (2007), fire safety can be generally defined as a systematic approach which combines the usage of structural materials, building components, and protective system. Besides, fire safety is generally divided into two separate categories: 'active' system and 'passive' system. The passive system mainly focuses on the physical aspect of the building such as compartmentation, escape routes, and ventilation system while the active system makes use of additional equipment or a group of system to detect and suppress the presence of fire. However, from a heritage conservation point of view, the active fire safety system is more practical since it rarely disturbs the original physical properties of the building. It is widely accepted by building conservators that the implementation of the fire safety system should contain the utmost minimal physical impact on the fabric and decor of the building. This is vital for heritage timber buildings since most of the physical elements of the buildings are irreplaceable and more fragile compared to another type of building materials.

Specific legislation was issued by every respective authority to provide a general guideline towards the implementation of the fire safety system in a 
building. Still, in most cases, these legislations did originally mean for new buildings and may not be compatible with the existing buildings including heritage buildings. According to Nurul Hamiruddin \& A Ghafar (2009), most of the legislations in Malaysia are still lacking in terms of a proper guideline for fire safety implementation in heritage buildings. Nonetheless, Kidd (2010) stated that while it may not be applied to the heritage building, it is important to not overlook the fundamental point of its implementation. These legislations can be used as a reference to provide a performance-based standard that best fit into the objectives of heritage building fire protection measures.

\section{FIRE SAFETY MEASURES IN HERITAGE TIMBER BUILDINGS \\ Selection of Case Study}

In order to determine the ideal fire safety measures in heritage timber buildings, it is important to identify the methods that are currently used by most of the heritage timber buildings in Malaysia. Malaysia has a considerable amount of heritage timber buildings around the country, in which, most of the buildings were adaptively re-used as museums or public attractions. Yet, heritage timber buildings that are easily accessible to the public tend to have a higher level of fire risk potential. Thus, these buildings need to incorporate an appropriate level of a fire safety system to not only protect the visitors but also the building itself.

Currently, most of the well-known or gazetted heritage timber buildings are under safeguarding by the state governments or private institutions. These buildings tend to have a specific budget allocated for the implementation of fire safety measures to a certain degree. This may include the usage of the detection system, suppression system, and methods of escape. The selection of buildings as a case study was determined by the age of building of more than 100 years, building availability to the public, and building that is under safeguarding by federal or state government agency. Based on the above factors, four (4) heritage timber buildings were selected which are (1) Istana Ampang Tinggi, Seremban, Negeri Sembilan, (2) Negeri Sembilan Traditional House, Seremban, Negeri Sembilan, (3) Muzium Matang, Perak, and (4) Muzium Kota Kuala Kedah, Kedah.

These four buildings are currently gazetted as a heritage building under the National Heritage Act 2005. Both Istana Ampang Tinggi and Negeri Sembilan Traditional House are under the care of the Negeri Sembilan Museum Board. Whereby, Muzium Matang and Muzium Kota Kuala Kedah are under the direct supervision of the Department of Museums Malaysia. Nevertheless, each of the selected buildings is provided with a specific allocation for fire safety implementation annually. In terms of function, all four buildings are currently used as a museum except for Istana Ampang Tinggi and Negeri Sembilan Traditional House, which are used as part of the museum display. These buildings are easily accessible to the public and mostly open throughout the year. 
Nurul Hamiruddin Salleh \& Muhammad Alif Wajdi Mohtar

Active Fire Safety Measures in the Heritage Timber Buildings in Malaysia

\section{ANALYSIS \& FINDINGS}

Upon the completion of the observation, several similarities and differences in terms of fire safety measures were identified in each of the four buildings. These measures include the usage of the detection system and suppression system as well as the method of escape. The summary of the fire safety measures in all four buildings is shown in Table 5 .

Table 5: Summary of active fire safety measures in the heritage timber buildings

\begin{tabular}{lccc}
\hline \multicolumn{1}{c}{ Building } & $\begin{array}{c}\text { Detector } \\
\text { System }\end{array}$ & Suppression System & Other \\
\hline $\begin{array}{l}\text { Istana Ampang } \\
\text { Tinggi }\end{array}$ & Smoke detector & ABC fire extinguisher & Emergency light \\
\hline $\begin{array}{l}\text { Negeri Sembilan } \\
\text { Traditional House }\end{array}$ & None & $\mathrm{ABC}$ fire extinguisher & Emergency light \\
\hline Muzium Matang & $\mathrm{CCTV}$ & $\begin{array}{c}\mathrm{ABC} \text { fire extinguisher } \\
\mathrm{CO}_{2} \text { fire extinguisher }\end{array}$ & $\begin{array}{c}\text { Emergency light } \\
\text { Exit sign }\end{array}$ \\
\hline $\begin{array}{l}\text { Muzium Kota } \\
\text { Kuala Kedah }\end{array}$ & $\mathrm{CCTV}$ & $\mathrm{ABC}$ fire extinguisher & None \\
\hline
\end{tabular}

One of the similar methods which can be identified in all of the four buildings is the usage of $\mathrm{ABC}$ Powder fire extinguisher as the main fire suppression system. However, due to the small size of the building, only one ABC Powder fire extinguisher is provided each for Istana Ampang Tinggi and Negeri Sembilan Traditional House. While, Muzium Kota Kuala Kedah is equipped with two ABC Powder fire extinguishers. Since Muzium Matang consists of two separate floors and larger floor area, it is equipped with six $\mathrm{ABC}$ Powder fire extinguishers, one on the ground floor and five on the first floor. Also, two $\mathrm{CO}_{2}$ fire extinguishers are equipped on the ground floor of Muzium Matang. This is most likely due to the presence of the control panel used for the alarm system next to the registration counter. While $\mathrm{ABC}$ Powder fire extinguishers are commonly used in most situations, $\mathrm{CO}_{2}$ fire extinguishers are deemed as an appropriate type of extinguisher when dealing with electrical fire since it is harmless to electrical equipment.

As for the detection system, only Istana Ampang Tinggi incorporates the usage of a photoelectric smoke detector inside the building. Even though Negeri Sembilan Traditional House is situated just right next to Istana Ampang Tinggi, no fire detection system can be found within the building. Similarly, both Muzium Matang and Muzium Kuala Kedah also did not incorporate any fire detection system but rely solely on the usage of closed-circuit television (n) system to monitor building security. The system is closely monitored 24-hour a day by the security guard on duty. However, the smoke detector system is 
considered a more viable option since it can detect the presence of smoke particles faster which may not be visible or easy to be seen through the camera.

Except for Muzium Kota Kuala Kedah, each of the heritage timber buildings is equipped with light-emitting diode (LED) emergency lights. These lights will help the occupants to navigate through the exits or escape routes during the evacuation process of the building in the event of loss of primary power. The location of each light is spread out throughout the whole building to provide the minimum level of coverage to each area of the building.

From the observation, each of the selected buildings is generally equipped with an appropriate amount of active fire protection system. However, the selection of equipment for each building is different when compared to one another. This is due to the difference in terms of the size of the building as well as the content inside the building. Since Istana Ampang Tinggi and Negeri Sembilan Traditional House are smaller than the other two buildings, the implementation of active fire protection measures is slightly minimal and less complicated. Moreover, there is hardly any content or valuable item on display inside both buildings. Therefore, the main focus of the building's fire safety is only to evacuate the occupants and prevent further damage to the building from the outside.

In comparison, Muzium Kota Kuala Kedah and Muzium Matang are bigger in terms of size especially Muzium Matang which comprises two floors. Unlike the two buildings from Negeri Sembilan, both buildings contain precious artefacts as well as various kinds of display items. Thus, this would also raise security concerns aside from fire safety-related matters. The usage of CCTV system is considered as the most viable option since it can act as both the surveillance system as well as fire detection system at the same time. However, the main concern is that the system relies too much on a human presence to monitor the status of the building.

\section{CONCLUSIONS}

The study had identified that all the selected heritage timber buildings are equipped with very basic active fire safety measures. All the buildings rely on the limited portable fire extinguishers as the main suppression system. Indeed, the system is cost-effective and minimally invasive to the buildings but with limited functionality. Thus, due to the main building material is using timbers, the buildings are still considered highly exposed to the threats of fire. The study also found that financial constraints remain as the main setback in providing good active fire safety measures in the selected heritage buildings. Furthermore, fire safety awareness among the building owners is still very low in which the security aspects are given more priority instead of safety. Therefore, reliable fire safety management should be in place to protect the safety of people (visitors) as well 
Nurul Hamiruddin Salleh \& Muhammad Alif Wajdi Mohtar

Active Fire Safety Measures in the Heritage Timber Buildings in Malaysia

as the safety of the heritage timber buildings. A fire accident can happen at any time that may cause the priceless building badly damaged or destroyed.

\section{ACKNOWLEDGEMENT}

This research was funded under the Fundamental Research Grant Scheme from the Ministry of Higher Education Malaysia (FRGS15-192-0433).

\section{REFERENCES}

Department of Standards Malaysia. (2001). Part 9: Fire Resistance of Timber Structures. In MS 544: Code of Practice for Structural Use of Timber.

Farid Wajdi Akashah, Syarifah Nadirah Wan Teh \& Baaki, T.K. (2016). Fire Risk Assessment of Historic Buildings in Malacca World Heritage Site. The Malaysian Surveyor, 51(4):30-38.

Gerard, R., \& Barber, D. (2013). Fire Safety Challenges of Tall Wood Buildings. Arup North America, (December), 131. http://doi.org/10.1007/978-1-4614-8142-3

Maxwell, I. (2005). Fire safety Creating an Awareness of Fire Threat. Edinburgh: Historic Scotland

Kidd, S. (2010). Fire Safety Management in Traditional Buildings Part 1. Guide for Practitioners. Edinburgh: Historic Scotland.

Lowden, L., \& Hull, T. (2013). Flammability behaviour of wood and a review of the methods for its reduction. Fire Science Reviews, 2(1), 4. http://doi.org/10.1186/2193-0414-2-4

National Fire Protection Association. (2015). NFPA 914: Code for Fire Protection of Historic Structures. Quincy: NFPA

National Heritage Act 2005 (Act 645) (2006). Petaling Jaya: International Law Book Services

Nurul Hamiruddin Salleh, \& A Ghafar Ahmad. (2009). Fire Safety Management in Heritage Buildings : the Current Scenario in Malaysia. 22nd CIPA Symposium.

Nurul Hamiruddin Salleh (2011). Fire Safety in Heritage Buildings: Life Vs Property Safety. In Heritage Study of Muslim World. Kuala Lumpur: IIUM Press, p. 61-72.

Othuman Mydin, M.A., Md Sani, N., Abas, N.F. \& Khaw, Y.Y. (2014). Evaluation of Fire Hazard and Safety Management of Heritage Buildings in Georgetown, Penang. MATEC Web of Conferences 10.

Rozrinda Roslan \& Shahrul Yani Said (2017). Fire Safety Management for Heritage Buildings in Malaysia. Environment-Behaviour Proceedings Journal (E-BPJ), 2(6), Nov. 2017, p, 221-226.

U.S. Department of Housing and Urban Development. (2007). The Effects of Fire on Structural Systems. Retrieved July 24, 2016, from http://www.ashireporter.org/HomeInspection/Articles/The-Effects-of-Fire-onStructural-Systems/1154

Urquhart, D. (2007). Conversion of Traditional Buildings. Guide for Practitioners (Vol. 6). Edinburgh: Historic Scotland. Retrieved from www.historicscotland.gov.uk/publicationsresults.html.

Received: January 2020. Accepted: $1^{\text {st }}$ April 2020 